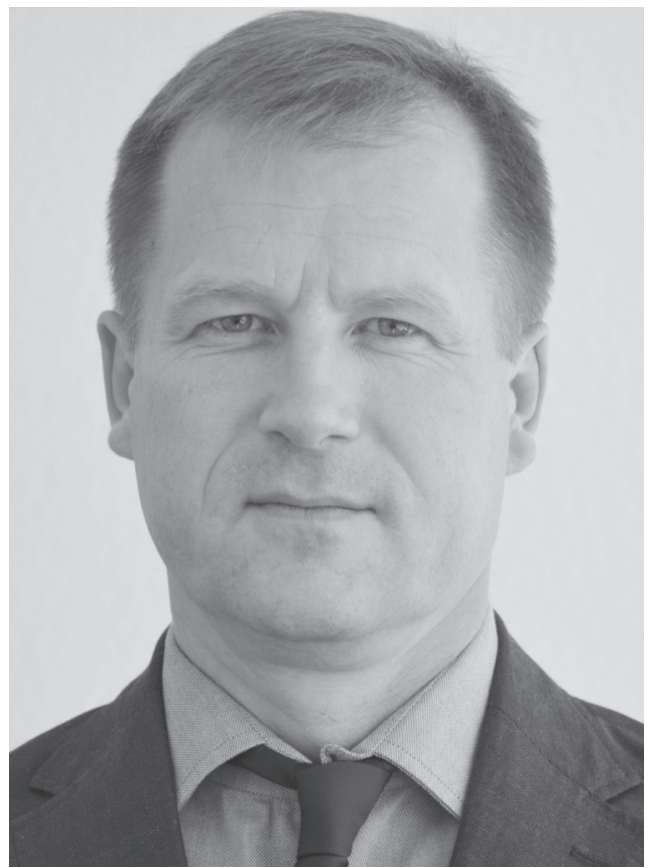

UDC: 343.9:343.352(477)

DOI: https://doi.org/10.32689/2617-

2224-2019-17-2-250-260

Radetsky Ruslan Stanislavovich, Associate Professor, Department of Public Administration and Administration, Institute of Personnel Training of the State Employment Service of Ukraine, 03038 Kyiv, Str. Novovokzalna, 17, tel/fax: (044) 53614 85,email:radeckyr@gmail.com ORCID: 0000-0001-5731-6151

Радецький Руслан Станіславович, доцент кафедри публічного управління та адміністрування, Інститут підготовки кадрів державної служби зайнятості Украӥни, 03038 м. Киів, вул. Нововокзальна, 17, тел/факс: (044) 5361485 , email: radeckyr@gmail.com

$$
\text { ORCID: 0000-0001-5731-6151 }
$$

Радецкий Руслан Станиславович, дочент кафедры публичного управления и администрирования, Институт подготовки кадров государственной службы занятости Украины, 03038 м. Киев, ул. Нововокзальная, 17, тел/факс: (044) 53614 85, email: radeckyr@gmail.com

ORCID: 0000-0001-5731-6151

\title{
SYSTEM AGAINST CORRUPTION IN UKRAINE: PROBLEMS OF INTERACTION OF SUBJECTS
}

Abstract. The article reveals problems of interaction of subjects in the system of combating corruption in Ukraine. The current legislation in the field of combating corruption is investigated and the main problems of combating this phenomenon in Ukraine are revealed. The author analyzed the institutional framework in the field of combating corruption, identified the main functions of the subjects of the anti-corruption system in Ukraine, and analyzed the problems of interaction between the subjects of the system. The author also managed to distinguish the preventive function of the National Agency for the Prevention of Corruption and the prospects of this body. It was clarified that Ukraine has undertaken a number of commitments on the way to the fastest possible integration into the European Community, the most priority of which is an effective, uncompromising and continuous struggle against corruption, which challenges the comprehensive development of all spheres of life in our country. To this end, a number of institutions have been created that are leading the fight against this phenomenon. Thus, in the structure of the Prosecutor General's Office a sepa- 
rate anti-corruption body was established - the Specialized Anti-Corruption Prosecutor's Office and separately - the National Anti-Corruption Bureau of Ukraine, which are the security forces and are investigating and punishing the perpetrators of corrupt acts. However, there is another agency that plays a leading role in the anti-corruption struggle in Ukraine - the National Agency for the Prevention of Corruption, which implements a preventive function whose activities include preventing and detecting corruption, declaring income and expenses, identifying a conflict of interest, as well as counteracting political corruption. It is proved that all efforts in the fight against corruption in Ukraine should be carried out with the understanding that the center of its consequences is an average citizen. Therefore, effective public policy in this area is one of the main factors of the state authorities' concern for citizens. After the Dvor Revolution, the fight against corruption has started to work in a new way and is the most priority in the direction of Ukraine's European integration. This is evidenced by the adoption of a number of anti-corruption laws and the creation of institutions for the prevention and fight against corruption.

Keywords: anti-corruption policy, corruption, preventive function, the system of fighting corruption, the subjects of the system.

\section{СИСТЕМА БОРОТЬБИ 3 КОРУПЦІЕЮ В УКРАЇНІ: ПРОБЛЕМИ ВЗАЕМОДІї СУБ'ЄКТІВ}

Анотація. Виявлено проблеми взаємодії суб'єктів в системі боротьби з корупцією в Україні. Досліджено чинне законодавство у сфері боротьби з корупцією та виявлено основні проблеми боротьби з цим явищем в Україні. Проаналізовано інституційну базу у сфері протидії корупції, виявлено основні функції суб’єктів системи боротьби з корупцією в Україні та проаналізовано проблеми взаємодії суб'єктів системи. Також виокремлено превентивну функцію Національного агентства з питань запобігання корупції та перспективи роботи цього органу. З'ясовано, що шляхом якомога швидшої інтеграції до Європейського співтовариства, Україна взяла низку зобов’язань, найпріоритетнішим з яких є ефективна, безкомпромісна та постійна боротьба з корупцією, яка кидає виклик всебічному розвитку всіх сфер життя в нашій державі. 3 цією метою створено ряд інституцій. Так, у структурі Генпрокуратури створено окремий орган по боротьбі з корупцією - Спеціалізовану антикорупційну прокуратуру та окремо - Національне антикорупційне бюро України, які є силовими структурами і займаються розслідуваннями і покаранням винних у корупційних діяннях осіб. Проте, є ще одне відомство - Національне агентство з питань запобігання корупції, що реалізовує превентивну функцію, до сфери діяльності якого належать запобігання та виявлення корупції, декларування доходів та видатків, виявлення конфлікту інтересів, а також протидія політичній корупції. Доведено, що всі зусилля у боротьбі з корупцією в Україні мають відбуватися з розумінням того, що центром іiї наслідків $є$ пересічний громадянин. Тому ефективна державна політика в цій сфері є одним з основних чинників 
турботи державної влади про громадян. Про це свідчить прийняття низки антикорупційних законів та створення інституцій для попередження та боротьби з корупцією.

Ключові слова: антикорупційна політика, корупція, превентивна функція, система боротьби з корупцією, суб'єкти системи.

\section{СИСТЕМА БОРЬБЫ С КОРРУПЦИЕЙ В УКРАИНЕ: ПРОБЛЕМЫ ВЗАИМОДЕЙСТВИЯ СУБЪЕКТОВ}

Аннотация. Выявлены проблемы взаимодействия субъектов в системе борьбы с коррупцией в Украине. Исследовано действующее законодательство в сфере борьбы с коррупцией и выявлены основные проблемы борьбы с этим явлением в Украине. Проанализирована институциональная база в сфере противодействия коррупции, определены основные функции субъектов системы борьбы с коррупцией в Украине и проанализированы проблемы взаимодействия субъектов системы. Также выделена превентивная функция Национального агентства по вопросам предотвращения коррупции и перспективы работы этого органа. Выяснено, что став на путь скорейшей интеграции в Европейское сообщество, Украина взяла на себя ряд обязательств, приоритетным из которых является эффективная, бескомпромиссная и постоянная борьба с коррупцией, которая бросает вызов всестороннему развитию всех сфер жизни в нашем государстве. С этой целью создан ряд институтов. В структуре Генпрокуратуры создан отдельный орган по борьбе с коррупцией - Специализированная антикоррупционная прокуратура и отдельно - Национальное антикоррупционное бюро Украины, которые являются силовыми структурами и занимаются расследованиями и наказанием виновных в коррупционных деяниях лиц. Однако, есть еще одно ведомство - Национальное агентство по вопросам предотвращения коррупции, которое реализует превентивную функцию, к сфере деятельности которого входят предотвращения и выявления коррупции, декларирование доходов и расходов, выявление конфликта интересов, а также противодействие политической коррупции. Доказано, что все усилия в борьбе с коррупцией в Украине должны происходить с пониманием того, что центром ее последствий является рядовой гражданин. Поэтому эффективная государственная политика в этой сфере является одним из основных факторов заботы государственной власти о гражданах. Об этом свидетельствует принятие ряда антикоррупционных законов и создание институтов для предупреждения и борьбы с коррупцией.

Ключевые слова: антикоррупционная политика, коррупция, превентивная функция, система борьбы с коррупцией, субъекты системы.

Problem statement. Standing on the path of early integration into the
European community, Ukraine has undertaken a number of commitments, the 
most priority of which is an effective, uncompromising and constant fight against corruption, which challenges the comprehensive development of all spheres of life in our country. To this end, a number of institutions have been established to lead the fight against this phenomenon. Thus, in the structure of the Prosecutor General's office created a separate body to combat corruption a Specialized Anti-corruption Prosecutor's office and separately - the National Anti-corruption Bureau of Ukraine, which are law enforcement agencies and investigate and punish those responsible for corruption. However, there is another agency that plays one of the main roles in the anti-corruption struggle in Ukraine - the National Agency for the Prevention of Corruption, which implements a preventive function, which includes the prevention and detection of corruption, the declaration of income and expenses, the identification of conflicts of interest, as well as combating political corruption. This article will be devoted to the interaction between these institutions, as well as other public authorities.

Analysis of recent research and publications. Such leading scientists as H. Bozhok, A. Zakharchuk, T. Iliienok, A. Levchenko, A. Novak, D. Siryk, S. Shatrava and others were engaged in the study of the fight against corruption. However, the problems of interaction of authorities in the fight against corruption today are extremely acute and require scientific monitoring and support, which was the motive for choosing the topic of this scientific article.

The purpose of the article is to identify the problems of interaction of subjects in the system of combating corruption in Ukraine. According to the goal set in the article, it is necessary to solve a number of tasks, including: to study the current legislation in the field of combating corruption; to identify the main problems of combating this phenomenon in Ukraine; to analyze the institutional framework in the field of combating corruption; to identify the main functions of the subjects of the system of combating corruption in Ukraine; to analyze the problems of interaction of the subjects of the system; highlight the preventive function of the National Agency for the Prevention of Corruption and the prospects for the work of this body.

Presentation of the main material. Ukrainian researcher A. Novak notes that corruption as a social phenomenon has a number of reasons for its emergence and spread in the economic, political and socio-structural organization of society. The vast majority of its consequences are felt in real social life, affecting its level, the degree of protection of citizens, the security of their rights and freedoms. The purpose of anti-corruption policy in Ukraine should be to reduce the level and localization of corruption in society, change its nature, limit its impact on socio-political and economic processes [1]. One cannot but agree with this view, since all efforts to combat this phenomenon must be made with the understanding that the center of the consequences of corruption and the main object that suffers from it is the ordinary citizen. Therefore, an effective state policy in this area is one of the main factors of the state care of the authorities about citizens. 
The retrospective of the fight against corruption dates back to 1995, when the first legal act was adopted - the Law of Ukraine "On combating corruption", but this activity did not give the desired results and was apparently declarative. However, after the Revolution of Dignity, this direction has earned a new and is the most priority in the direction of European integration of Ukraine. This is evidenced by the adoption of a number of anti-corruption laws and the establishment of institutions to prevent and combat corruption.

Among the new anti-corruption laws, the main ones are as follows: "Anti-Corruption strategy for 2014-2017" approved by the Law of Ukraine "On the basics of the state anti-corruption policy in Ukraine (Anti-Corruption strategy) for 2014-2017" dated 14.10.2014 № 1699-VII and the Law of Ukraine "On prevention of corruption" dated 14.10.2014 № 1700-VII. Also recently new laws were adopted such as "On amendments to the criminal and criminal procedure codes of Ukraine on the implementation of the recommendations contained in the sixth report of the European Commission on the status of Ukraine's implementation of the action Plan on the liberalization of the visa regime for Ukraine by the European Union on the improvement of the procedure for the seizure of property and the Institute of special confiscation" dated 18.02.2016 № 1019, "On the National Agency for the identification, search and management of assets derived from corruption and other crimes" dated 10.11.2015 № 3040 and "On the State Bureau of Investigation” dated 12.11.2015 № 794-VIII, "On amendments to some legislative acts of Ukraine on the prevention and combating of political corruption" dated 08.10.2015 № 731-VIII, "On public service” dated 10.12.2015 № 889-VIII, "On the prevention of the impact of corruption offenses on the results of official sports competitions" dated 03.11.2015, № 743-VIII. This situation testifies to the consistent implementation of state policy and reforms in the system of combating corruption.

Thus, the main document that acts in the fight against corruption is the "Anti-Corruption strategy for 20142017", approved by the Law of Ukraine "On the basis of the state anti-corruption policy in Ukraine (Anti-Corruption strategy) for 2014-2017" dated 14.10.2014 № 1699-VII.

The main focus of the Strategy is on the following aspects [2]:

- prevention of corruption in the legislative, executive and judicial branches;

- system reform of the criminal justice system;

- enhancing the role of civil society and public awareness of the negative consequences of corruption;

- public and business participation in monitoring anti-corruption efforts.

It should be noted that the difference of this Strategy from the previous anti-corruption documents is that it regulates the submission of an annual public report on the progress of its implementation and provides indicators of the effectiveness of the implementation of anti-corruption struggle.

The law of Ukraine "On prevention of corruption" reflects radical changes in the system of fight against corruption in the country. This law 
requires new rules, a comprehensive and balanced approach to the control of anti-corruption measures by ensuring greater efficiency of parliamentary control, balancing the responsibility of presidential control, executive authorities and local administrations, as well as effective public control. The proposed innovations have expanded the list of preventive barriers and prohibitions for civil servants. The law introduces a new system of financial control over the state of property of civil servants: their declarations must be published online in the public domain and checked by an independent body. The law regulates the issues of anti-corruption restrictions in the process of appropriation of corporate opportunities, receiving gifts, secondary employment, joint work of close persons, and issues related to the termination of public service. For those civil servants who cannot explain their excessive costs, serious sanctions are stipulated [2].

The main insurmountable problems in this area, which are also specified in the Law of Ukraine "On the basis of the state anti-corruption policy in Ukraine (anti-Corruption strategy) for 20142017":

- passive cooperation of Ukraine towards the establishment of an effective coordinated anti-corruption policy among the States parties to the United Nations Convention against corruption of 31 October 2003 (this was repeatedly noted by the experts of Transparency International-Ukraine);

- Ukraine's inadequate implementation of the requirements of international legal instruments in relation to the partnership between the government and civil society in the field of anti- corruption policy (despite the adoption of a number of legal acts, one of them does not prescribe a clear mechanism of interaction between the state and public organizations in the direction of combating corruption; it is not implemented, or delayed the implementation of the recommendations of anti-corruption public organizations; there is no act of the Cabinet of Ministers of Ukraine on the adoption of a national methodology for assessing the level of corruption in accordance with UN standards, the development of which is clearly provided by the Law of Ukraine "On the basis of the state anti-corruption policy in Ukraine (anti-Corruption strategy) for 2014-2017");

- corruption of electoral legislation, in particular: imperfection of legislation on the financing of election campaigns and political parties, lack of proper legal regulation to prevent conflicts of interest in the activities of elected officials and transparent bases of lobbying [3].

So, as we see in Ukraine, a significant legislative framework on the prevention and fight against corruption has been developed, which indicates the consistent implementation of state policy and reforms in the system of combating corruption. However, there are a number of shortcomings that need to be addressed, which should be the focus of the entire system to combat this phenomenon.

Thus, we will get directly to the institutional environment that forms the system of combating corruption in Ukraine.

In the old anti-corruption system, numerous anti-corruption bodies formally operated. The Prosecutor General's office, the police, the Security 
Service of Ukraine, the Military Law Enforcement Service in the Armed forces, as well as a network of internal security, audit, financial and other controls. However, the level of trust of citizens of Ukraine to all national institutions and structures designed to: prevent and combat corruption" was extremely low. According to opinion polls, the level of trust of the Ukrainian society to these bodies for many years fluctuated within $7-15 \%$, thus the militia and Prosecutor's office took the last places [2].

As for the modern system, it is formed by a number of newly created specialized bodies, including the $\mathrm{Na}$ tional Agency for the Prevention of Corruption (NAPC), the National Anti-corruption Bureau of Ukraine (NABU) and the Specialized Anti- corruption Prosecutor's office (SAP), as well as other bodies that have a set of functions to combat corruption in Ukraine.

The main functions of the subjects of the anti-corruption system are provided in Table.

Thus, as can be seen from the table, the system of prevention of corruption in Ukraine includes a significant number of entities that perform a set of functions that are designed to combat this negative phenomenon in our country.

It should be noted that one of the key lessons of previous anti-corruption reforms in Ukraine is the inefficiency of attempts to change the system by reforming individual structures or processes, rather than the overall situation

The main functions of the subjects of the anti-corruption system in Ukraine*

\begin{tabular}{|c|c|c|}
\hline № & $\begin{array}{c}\text { The name of the } \\
\text { authority }\end{array}$ & Main functions \\
\hline 1 & 2 & 3 \\
\hline 1 & $\begin{array}{l}\text { State Bureau of investi- } \\
\text { gation }(\mathrm{SBI})\end{array}$ & $\begin{array}{l}\text { law enforcement activities for the purpose of prevention, de- } \\
\text { tection, suppression, disclosure and investigation of crimes }\end{array}$ \\
\hline 2 & $\begin{array}{l}\text { National Anti-corruption } \\
\text { Bureau of Ukraine } \\
\text { (NABU) }\end{array}$ & $\begin{array}{l}\text { operational investigative measures; pre-trial investigation; } \\
\text { check on the integrity of persons authorized to perform the } \\
\text { functions of the state or local government; search and sei- } \\
\text { zure of funds and other property }\end{array}$ \\
\hline 3 & $\begin{array}{l}\text { Prosecutor's Office } \\
\text { of Ukraine }\end{array}$ & $\begin{array}{l}\text { maintenance of public prosecution in court; supervision of } \\
\text { compliance with laws }\end{array}$ \\
\hline 4 & $\begin{array}{l}\text { Specialized Anti-corrup- } \\
\text { tion Prosecutor's office }\end{array}$ & $\begin{array}{l}\text { supervision of compliance with the laws during the opera- } \\
\text { tional and investigative activities, pre-trial investigation of } \\
\text { NABU; support of the state prosecution in the relevant pro- } \\
\text { ceedings; representation of the interests of a citizen or the } \\
\text { state in court }\end{array}$ \\
\hline 5 & $\begin{array}{l}\text { National Agency } \\
\text { of Ukraine for detection, } \\
\text { search and manage- } \\
\text { ment of assets obtained } \\
\text { from corruption and } \\
\text { other crimes }\end{array}$ & $\begin{array}{l}\text { formation and implementation of the state policy in the } \\
\text { field of identification and search of assets; formation and } \\
\text { maintenance of the Unified state register of assets seized } \\
\text { in criminal proceedings; participation in ensuring the rep- } \\
\text { resentation of the rights and interests of Ukraine in foreign } \\
\text { jurisdictional bodies in cases related to the return to Ukraine } \\
\text { of assets derived from corruption and other crimes }\end{array}$ \\
\hline
\end{tabular}




\begin{tabular}{|c|c|c|}
\hline 1 & 2 & 3 \\
\hline 6 & $\begin{array}{l}\text { National Police } \\
\text { of Ukraine }\end{array}$ & $\begin{array}{l}\text { investigation of minor corruption crimes not related to the } \\
\text { jurisdiction of NABU or SBI and corruption administrative } \\
\text { offenses; maintenance of databases (banks) data on regis- } \\
\text { tered criminal and administrative corruption offenses }\end{array}$ \\
\hline 7 & $\begin{array}{l}\text { Ukrainian Security } \\
\text { Service (USS) }\end{array}$ & $\begin{array}{l}\text { prevention, detection, termination and disclosure of corrup- } \\
\text { tion and organized criminal activity }\end{array}$ \\
\hline 8 & $\begin{array}{l}\text { National Agency } \\
\text { for the Prevention } \\
\text { of Corruption (NAPC) }\end{array}$ & $\begin{array}{l}\text { formation and implementation of anti-corruption policy; } \\
\text { analysis of the state of prevention and combating corruption } \\
\text { in Ukraine; development of draft anti-Corruption strategy; } \\
\text { control and verification of declarations; maintenance of the } \\
\text { Unified state register of declarations and the Unified state } \\
\text { register of persons who committed corruption or corrup- } \\
\text { tion-related offenses; approval of rules of ethical behavior; } \\
\text { organization of training, retraining and advanced training on } \\
\text { issues related to the prevention of corruption }\end{array}$ \\
\hline 9 & $\begin{array}{l}\text { National Council } \\
\text { on Anti-corruption } \\
\text { Policy }\end{array}$ & $\begin{array}{l}\text { preparation and submission of proposals to the President } \\
\text { of Ukraine on the formation and implementation of the state } \\
\text { anti-corruption policy; analysis of the state of prevention } \\
\text { and combating corruption in Ukraine }\end{array}$ \\
\hline 10 & $\begin{array}{l}\text { Committee of the Verk- } \\
\text { hovna Rada of Ukraine } \\
\text { on prevention and } \\
\text { combating corruption }\end{array}$ & $\begin{array}{l}\text { anti-corruption expertise of draft legislation; legal regula- } \\
\text { tion of the activities of NABU and NAPC; legal regulation of } \\
\text { the activities of other bodies in the sphere of prevention and } \\
\text { counteraction of corruption }\end{array}$ \\
\hline 11 & $\begin{array}{l}\text { Ministry of justice } \\
\text { of Ukraine }\end{array}$ & $\begin{array}{l}\text { anti-corruption expertise of normative legal acts; inspec- } \\
\text { tion, under the Law of Ukraine "On government cleansing"; } \\
\text { the formation and maintenance of the Unified state register } \\
\text { of lustrated persons }\end{array}$ \\
\hline 12 & $\begin{array}{l}\text { Government Commis- } \\
\text { sioner for anti-corrup- } \\
\text { tion policy }\end{array}$ & $\begin{array}{l}\text { formation and ensuring the implementation of the state anti- } \\
\text { corruption policy in the executive authorities }\end{array}$ \\
\hline
\end{tabular}

in politics, society and security. Due to the complete public distrust of the former government as a whole and, including, anti-corruption bodies, it was impossible to achieve any noticeable systemic success in overcoming corruption [2].

A key area that needs to be implemented in Ukraine is the establishment of effective cooperation of all subjects of the anti-corruption system.

However, unfortunately, today there is a partial confrontation between these players, that are sometimes overlapping powers and lack of full cooperation, which significantly hinders the process of eradicating corruption and combating this phenomenon.

An example of this was the approval of the Procedure for monitoring and full verification of electronic declarations of officials, during which there was some incomprehensible confrontation between the Ministry of justice and the NAPC. However, it should be noted that the position of the Minister of justice in criticizing the work of NAPC is unreasonable and indicates 
inconsistency in the work, which negatively affects the trust of citizens to the entire system of prevention of corruption in Ukraine. It should be noted that unlike other bodies that implement the power and punitive function, NAPC performs preventive, which is extremely important, because the prevention of this phenomenon is one of the key principles of the struggle, which puts before itself not only Ukraine but also the leading European countries. Warning is the basis of this policy.

In its preventive role, NAPC sets the following objectives [5]:

- ensuring effective work of preventive anti-corruption units;

- introduction of anti-corruption programs in the activities of public authorities;

- improving the standards of integrity of officials;

- ensuring the effective functioning of the Unified state register of declarations of persons authorized to perform the functions of the state or local self-government in order to effectively monitor compliance with the requirements of the legislation on the submission of e-declarations and proper verification of submitted declarations and identify violations of financial control requirements;

- improvement of the system of state control over party finances to ensure transparency of financing of political parties with the restriction of the influence of private capital on the policy and publicity of information on the financing of political parties;

- obtaining special permission to carry out activities related to state secrets, registration of admission and granting access to it to the relevant em- ployees of the National Agency for the purpose of full control of the submitted declarations of citizens, including law enforcement officers;

- monitoring the level of corruption in Ukraine, according to the approved methodology of the standard survey on the level of corruption in Ukraine;

- development of a new anti-corruption strategy based on the analysis of the results of assessing the level of corruption in Ukraine and the state of implementation of the current strategy, which will end in 2017.

Therefore, in order to ensure the proper functioning of the anti-corruption system in Ukraine, it is necessary to eliminate the shortcomings of the legislation in this area and improve the interaction of all subjects of this system, which will contribute to more effective work and increase public confidence in the work of anti-corruption bodies.

Summary. So, the study performed allows us to make certain generalizations and conclusions. All efforts in the fight against corruption in Ukraine should be made with the understanding that the center of its consequences is an ordinary citizen. Therefore, an effective state policy in this area is one of the main factors of the state care of the authorities about citizens. After the Revolution of Dignity, the direction of the fight against corruption has earned a new and is the most priority in the direction of European integration of Ukraine. This is evidenced by the adoption of a number of anti-corruption laws and the establishment of institutions to prevent and combat corruption. The main document in the fight against corruption is the "Anti-Corruption strategy for 2014-2017". The difference of 
this Strategy from the previous anticorruption documents is that it regulates the submission of an annual public report on the progress of its implementation and provides indicators of the effectiveness of the implementation of anti-corruption struggle. The system of prevention of corruption in Ukraine includes a significant number of entities that perform a set of functions designed to combat this negative phenomenon in our country. The main problems in the fight against corruption are as follows: passive cooperation of Ukraine in the direction of establishing an effective coordinated anti-corruption policy among the States parties to the United Nations Convention against corruption, inadequate implementation by Ukraine of the requirements of international legal instruments in relation to the partnership between the government and civil society in the field of anti-corruption policy and the corruption of electoral legislation. A key area that needs to be implemented in Ukraine is the establishment of effective cooperation of all subjects of the anti-corruption system. Therefore, in order to ensure the proper functioning of the anti-corruption system in Ukraine, it is necessary to eliminate the shortcomings of the legislation in this area and improve the interaction of all subjects of this system, which will contribute to more effective work and increase public confidence in the work of anti-corruption bodies.

\section{REFERENCES}

1. Novak A. (2016). Teoretychni osnovy doslidzhennia protydii koruptsiinym proiavam u systemi publichnoho upravlinnia [Theoretical Foundations of the Anti-Corruption Research in the Public Administration System]. Derzhavne upravlinnia ta mistseve samovriaduvannia - Public Administration and Local Self-Government, 1, 29-36 [in Ukrainian].

2. Antykoruptsiini zakhody v Ukraini pislia Revoliutsii Hidnosti: Kliuchovi zakonodavchi aspekty [Anticorruption in Ukraine after the Revolution of Dignity: Key Legislative Aspects]. (2016). Kyiv: Tsentr doslidzhen armii, konversii ta rozzbroiennia [in Ukrainian].

3. Zakon Ukrainy "Pro zasady derzhavnoi antykoruptsiinoi polityky $\mathrm{v}$ Ukraini (Antykoruptsiina stratehiia) na 2014-2017 roky" : vid 14 zhovtnia 2014, № 1699-VII [Law of Ukraine "On the Principles of State Anti-Corruption Policy in Ukraine (Anticorruption Strategy) for 2014-2017" from October 142014 roku, № 1699-VII]. (n.d.). zakon.rada.gov.ua. Retrieved from http://zakon3.rada.gov.ua/laws/ show/1699-18 [in Ukrainian].

4. Zakon Ukrainy "Pro zapobihannia koruptsii" : vid 14 zhovtnia 2014 roku, № 1700-VII [Law of Ukraine "On Prevention of Corruption" from October 14 2014, № 1700-VII]. (n.d.). zakon. rada.gov.ua. Retrieved from http://zakon2.rada.gov.ua/laws/show/1700-18 [in Ukrainian].

5. Zvit pro diialnist Natsionalnoho ahentstva z pytan zapobihannia koruptsii za 2016 rik [Report on the activities of the National Agency for the Prevention of Corruption for 2016]. (2017). nazk.gov.ua. Retrieved from https:// nazk.gov.ua/sites/default/files/docs/ nazk_files/zvity/NAPK_annual-report_2016.pdf [in Ukrainian].

\section{СПИСОК ВИКОРИСТАНИХ ДЖЕРЕЛ}

1. Новак А. Теоретичні основи дослідження протидії корупційним про- 
явам у системі публічного управління / А. Новак // Державне управління та місцеве самоврядування. - 2016. - Вип. 1. - С. 29-36.

2. Антикорупційні заходи в Україні після Революції Гідності: Ключові законодавчі аспекти, 2016. - Центр досліджень армії, конверсії та роззброєння. - Київ, 2016. - 224 с.

3. Про засади державної антикорупційної політики в Україні (Антикорупційна стратегія) на 2014-2017 роки: Закон України від 14 жовтня 2014 року № 1699-VII [Електронний pecypc]. - Режим доступу: http:// zakon3.rada.gov.ua/laws/show/169918

4. Про запобігання корупції: Закон України від 14 жовтня 2014 року № 1700-VII [Електронний ресурс]. Режим доступу: http://zakon2.rada. gov.ua/laws/show/1700-18

5. Звіт про діяльність Національного агентства 3 питань запобігання корупції за 2016 рік [Електронний ресурс]. - Режим доступу: ftp://91.142.175.4/nazk_files/zvity/ NAPK_annual-report_2016.pdf 